\title{
Snow globe
}

Jessica Frey, MD

Neurology ${ }^{\circledR}$ 2020;95:360. doi:10.1212/WNL.0000000000010247
Correspondence

Dr. Frey

Jess.el.frey@gmail.com

It was after I finished showing her the scans that she nose-dived away from the computer and back to the side of the bed.

She interlaced her fingers with the patient's own and begged her to do something,

anything,

smile, wake up, say your name, anything.

She didn't ask me any questions.

Seventeen millimeters.

With a midline shift like that, anyone can see: the brain is not where it belongs.

Her world is a snow globe now.

She holds it in the palm of her hand.

Shake shake:

maybe if she shakes it hard enough, maybe,

she can rearrange the snow,

the hospital bed, and the lady lying there.

Maybe everything will lift up and

float

for a moment

before settling back down

like gold leaves

that crumple into brown

and float for a moment

before dusting the ground.

I want to take the snow globe from her hands.

I want to tell her it doesn't work that way.

But instead I back out of the room,

afraid that if I stay, I may disturb the snow.

And just for a moment,

everything is right where it belongs. 


\title{
Neurology
}

\author{
Snow globe \\ Jessica Frey \\ Neurology 2020;95;360 Published Online before print July 10, 2020 \\ DOI 10.1212/WNL.0000000000010247
}

This information is current as of July 10, 2020

Updated Information \&
Services

Subspecialty Collections

Permissions \& Licensing

Reprints including high resolution figures, can be found at:

http://n.neurology.org/content/95/8/360.full

This article, along with others on similar topics, appears in the

following collection(s):

Coma

http://n.neurology.org/cgi/collection/coma

CT

http://n.neurology.org/cgi/collection/ct

Infarction

http://n.neurology.org/cgi/collection/infarction

Palliative care

http://n.neurology.org/cgi/collection/palliative_care

Prognosis

http://n.neurology.org/cgi/collection/prognosis

Information about reproducing this article in parts (figures,tables) or in its entirety can be found online at:

http://www.neurology.org/about/about_the_journal\#permissions

Information about ordering reprints can be found online:

http://n.neurology.org/subscribers/advertise

Neurology ${ }^{\circledR}$ is the official journal of the American Academy of Neurology. Published continuously since 1951, it is now a weekly with 48 issues per year. Copyright @ 2020 American Academy of Neurology. All rights reserved. Print ISSN: 0028-3878. Online ISSN: 1526-632X.

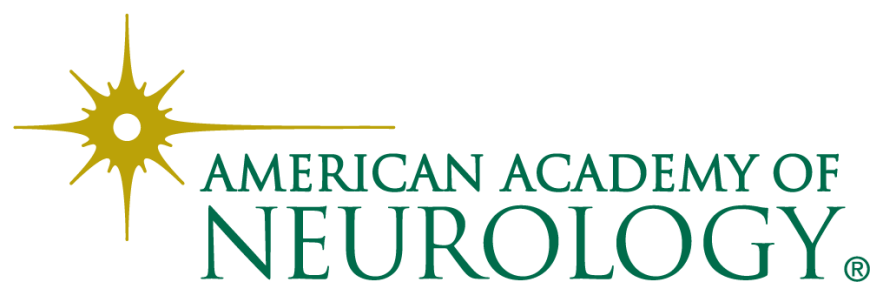

